\title{
Low frequency of side effects following an incidental 25 times concentrated dose of yellow fever vaccine
}

\author{
Baixa frequência de efeitos colaterais após administração acidental da \\ vacina contra febre amarela em dose 25 vezes concentrada
Ana Rabello', Marcela Orsini' ${ }^{1}$, Jolande Disch'1, Tânia Marcial' ${ }^{4}$, Maria da Luz F. Leal ${ }^{2}$, Marcos da Silva Freire ${ }^{2}$, Anna M. Yoshida Yamamura ${ }^{2}$ and Angelo Viana ${ }^{3}$

\begin{abstract}
In August/1999, a group of 14 adults from the staff of a private hospital in Contagem - Minas Gerais State, Brazil, received unintentionally a 25 times concentrated dose of the 17-DD yellow fever vaccine (BioManguinhos), due to a mistake at the reconstitution step. All patients were clinically and laboratorially evaluated at days 5, 13 and 35 post vaccination. Frequency of side effects and clinical observations of this group of individuals were not different from the observed in recipients immunized with normal doses of the vaccine. At the second and third evaluation none of the subjects reported symptoms. None of the patients presented abnormalities at the physical examination at none of the time points and in all cases the blood examination was normal, except for a reduced number of platelets that was detected in one subject at the first and second evaluation and reverted to normal at third evaluation. At the first evaluation point, 8 subjects were serum negative and 6 serum positive for yellow fever at the plaque reduction neutralization test. In 5 subjects the observed titre was 10 times higher as the baseline of $2.36 \mathrm{Log}_{10} \mathrm{mUI} / \mathrm{ml}$. The samples collected at second and third evaluation $\left(13^{\text {th }}\right.$ and $35^{\text {th }}$ days) demonstrated that all subjects responded to the vaccination with the exception of one that did not present a positive result in any of the samples collected. This evaluation confirms the safety of the 17DD yellow fever vaccine.
\end{abstract}

Key-words: Yellow fever. Vaccination. Safety.

Resumo Em agosto/1999, em conseqüência de engano na etapa de diluição, um grupo de 14 funcionários de um hospital privado de Contagem - Minas Gerais, Brasil, foi imunizado com uma dose 25 vezes mais concentrada do que a recomendada da vacina 17-DD contra febre amarela (Biomanguinhos). Todos o pacientes foram acompanhados através de exames clínicos e laboratoriais nos dias 5, 13 e 35 após a imunização. A freqüência de efeitos colaterais e as manifestações clínicas e laboratoriais não diferiram das observadas em indivíduos imunizados com doses convencionais da vacina. Ao tempo da segunda e terceira avaliações, nenhum dos pacientes relatava sintomas e nenhum deles apresentou anormalidades ao exame físico. Apenas um paciente apresentou alteração laboratorial, sendo observada plaquetopenia no momento da primeira e da segunda avaliação, que retornou aos valores normais ao terceiro exame. À primeira avaliação, seis pacientes apresentavam resposta imune ao teste de redução de neutralização em placa. Em cinco pacientes, o título foi 10 vezes maior do que o valor de corte de $2.36 \mathrm{Log}_{10} \mathrm{mUI} / \mathrm{ml}$. As amostras de sangue colhidas aos tempos 2 e 3 (13 e 35 dias) demonstraram que quase todos os indivíduos responderam à vacinação, com a exceção de um que não apresentou positividade em nenhum dos tempos de avaliação. Este episódio confirma a segurança da vacina $17-D D$ contra febre amarela.

Palavras-chaves: Febre amarela. Vacinação. Efeitos adversos.

\footnotetext{
1. Laboratório de Pesquisas Clínicas do Centro de Pesquisas René Rachou. 2. Instituto de Tecnologia em Imunobiológicos/Biomanguinhos da Fundação Oswaldo Cruz. 3. Secretaria de Saúde de Minas Gerais. 4. Secretaria Municipal de Saúde de Contagem, MG.

Endereço para correspondência: Dra. Ana Rabello. Laboratório de Pesquisas Clínicas/Centro de Pesquisas René Rachou/FIOCRUZ. Av. Augusto de Lima 1715, 30190-002 Belo Horizonte, MG

E-mail:ana@cpqrr.fiocruz.br

Recebido para publicação em 15/5/2001.
} 
Yellow fever, for which no specific treatment is available, ranges in severity from an undifferentiated self-limited grippe-like to an hemorrhagic fever that is fatal in $50 \%$ of cases. There are two epidemiological patterns of yellow fever transmission: the forest cycle, which has monkeys as hosts and is transmitted by wild mosquitoes (Haemagogus and Sabethes) that bit the people who enter the jungle, and the urban cycle, transmitted from human to human by the mosquito Aedes aegypti ${ }^{3}$. The forest form is endemic in Brazil and neighbour countries. The urban form had been eradicated in the Americas since $1942^{3}$.

Nowadays, Brazil is reinfested with Aedes aegypti that is also the vector and main transmitter of dengue. In order to avoid the return of the urban yellow fever, the Fundação Nacional da Saúde ( FUNASA)/Brazilian Ministry of Health, from December 1998 has launched a plan for the intensification of yellow fever vaccination. It aims to vaccinate every Brazilian older than six months, specially in areas like Legal Amazon, Mid-West Region and parts of the Maranhão State ${ }^{5}$.

The 17DD Yellow fever vaccine has been produced since 1937 in the former Instituto Oswaldo Cruz and since 1976 in Bio-Manguinhos, Fundação Oswaldo $\mathrm{Cruz}^{1011}$. This vaccine is of widespread use in enzootic areas and recommended for travelers and laboratory staff dealing with wild strains of the virus. Therefore, for more than 60 years the safety and efficacy of this vaccine has been established.

The vaccine is released in vials containing 50 freeze-dried doses supplemented with another vial of $25 \mathrm{ml}$ vaccine diluent. The vaccine must be first reconstituted with $1 \mathrm{ml}$ of chilled diluent and gently shaken. After complete reconstitution the suspension must be transferred to the vial containing the remainder $24 \mathrm{ml}$ of diluent and again gently shaken until complete homogenization. Each vaccine dose consists on $0,5 \mathrm{ml}$ of the final suspension and contains at least 1000 $L D_{50}$ of the 17DD strain of yellow fever virus ${ }^{15}$. The yellow fever vaccine is thermos-stable and maintain the adequate potency over the expiration date, even after distribution and go through the cold chain (unpublished data).

Due to a mistake during vaccine reconstitution, members of the staff of a private hospital in Minas Gerais, Brazil, received 25 times the recommended dose of the vaccine. This report describes the clinical and serological investigation of the individuals involved in this accident.

\section{PATIENTS AND METHODS}

In August/1999, a group of 14 adults from the staff of a private hospital in Contagem - Minas Gerais State, Brazil, unintentionally received a 25 times concentrated dose of the 17-DD Yellow Fever vaccine (BioManguinhos), due to a mistake at the dilution step. All were employees of the hospital and received the vaccine as part of an immunization campaign organized by the hospital and the Municipal Public Health Division.

The mistake was noticed on day one post vaccination (p.v). On day three p.v. the team of Fundação Oswaldo Cruz and the Division of Public Health of Contagem were contacted. Due to the hospital administrative restrictions the investigation started only on day five. All patients agreed to participate and signed an informed consent concerning the use of the data for scientific publication.
From the start of the follow-up period, during a six-week period, all patients were invited for three evaluations at days 5,13 and 35 post vaccination. During each of these recalls patients were submitted to a clinical examination and answered to a questionnaire addressing clinical signs and symptoms.

Haematological, biochemical and serological determinations. At the three time points in the followup period blood was collected for haematological and biochemical determinations (red blood cells, hematocrit, haemoglobin, leukocytes, platelets, urea, creatinin, glycemia, TGO, TGP, amylase, alkaline phosphatase, time of prothrombin, total and fractionate bilirubin), viremia ${ }^{14}$, and anti-yellow fever virus antibodies ${ }^{12}$.

\section{RESULTS}

Of the 14 subjects, mean age of 33.9 (22 - 62), $10(71.4 \%)$ were female. One was physician, one nurse, five nurse assistants, two guards, two receptionists, one cleaning woman, a scientist in biology, and an instrument passer. All patients adhered to the questionnaire during the entire follow-up period. Table 1 presents the proportion of subjects that informed presence of events temporary associated to the vaccine at the first evaluation. The hipertonic reconstituted vaccine can explain the pain at application site. At the second and third evaluation none of the subjects reported symptoms.

None of the patients presented abnormalities at the physical examination at none of the time points and in all cases the blood examination was normal. Reduced number of platelets was detected in one subject at the first and second evaluation that had reverted to normal at third evaluation. No other alterations were observed for none of the parameters.

At the first biochemical evaluation one subject presented an increased concentration of alkaline phosphatase. At the second evaluation one subject presented an increased TGO concentration. At the last evaluation two subjects presented alteration being one with an increased TGP concentration and one with an increased alkaline phosphatase concentration. 
Table 1 - Frequency of side effects on day seven after 25 times concentrated dose of yellow fever vaccination in the 14 individuals.

\begin{tabular}{lrrlrr}
\hline Effects & $\mathrm{nr}$ & $\%$ & Effects & $\mathrm{nr}$ & $\%$ \\
\hline Pain at application site & 8 & 57.1 & rash & 0 & \\
Muscular pain & 3 & 21.4 & itch & 0 & \\
Joint pain & 2 & 14.3 & weakness & 1 & 7.1 \\
Anorexia & 0 & & fever & 2 & 14.3 \\
Sickness & 1 & \multirow{2}{*}{7,1} & palpitations & 0 & \\
Abdominal pain & 0 & & skin lesions & 0 & \\
Dizziness & 2 & \multirow{2}{*}{14.3} & headache & 4 & 28.6 \\
Edema & 0 & & others & 0 & \\
\hline
\end{tabular}

Table 2 presents both viremia determination at first evaluation, and plaque neutralization test at all 3 evaluation points of all 14 vaccinated subjects. In only two samples it was possible to isolate virus using the quantitative plaque method in VERO cells.
At the first evaluation point, 8 subjects were serum negative and 6 serum positive for yellow fever at the plaque reduction neutralization test (Table 2). The absence of a pre-vaccination blood sample hampers confirmation of pre-existence of anti-yellow fever

Table 2 - Viremia determination at first evaluation, and plaque reduction neutralization tests at all 3 evaluation points of all 14 vaccinated subjects.

\begin{tabular}{|c|c|c|c|c|}
\hline \multirow[b]{2}{*}{ Subject } & \multirow{2}{*}{$\begin{array}{l}\text { Viremia } \\
\text { Pfu/ml }\end{array}$} & \multicolumn{3}{|c|}{ Plaque reduction neutralization test ${ }^{\star}$} \\
\hline & & $\begin{array}{c}\log _{10} \text { evaluation } 1 \\
5^{\text {th }} \text { day }\end{array}$ & $\begin{array}{c}\text { evaluation } 2 \\
13^{\text {th }} \text { day }\end{array}$ & $\begin{array}{c}\text { evaluation } 3 \\
35^{\text {th }} \text { day }\end{array}$ \\
\hline 1 & $<0.88$ & $2.75^{\star}$ & 4.46 & 4.14 \\
\hline 2 & $<0.88$ & negative & 3.86 & $>4.46$ \\
\hline 3 & $<0.88$ & negative & 4.06 & 3.65 \\
\hline 4 & $<0.88$ & negative & 3.22 & 3.48 \\
\hline 5 & $<0.88$ & negative & 3.66 & 3.96 \\
\hline 6 & $<0.88$ & negative & 3.86 & 4.39 \\
\hline 7 & 0.88 & negative & $>4.46$ & 3.75 \\
\hline $8^{* *}$ & $<0.88$ & negative & negative & negative \\
\hline 9 & $<0.88$ & 3.41 & 4.16 & 4.02 \\
\hline 10 & 1.65 & negative & 4.35 & - \\
\hline 11 & $<0.88$ & 3.41 & - & - \\
\hline 12 & $<0.88$ & 4.27 & - & 3.78 \\
\hline 13 & $<0.88$ & 3.77 & 4.29 & - \\
\hline 14 & $<0.88$ & 3.86 & - & - \\
\hline
\end{tabular}

antibodies and haematological and biochemical alterations. In 5 subjects the observed titre was 10 times higher as the baseline of $2.36 \log _{10} \mathrm{mIU} / \mathrm{ml}$. The samples collected at second and third evaluation $\left(13^{\text {th }}\right.$ and $35^{\text {th }}$ days) demonstrated that all subjects responded to the vaccination with the exception of one that did not present a positive result in any of the samples collected. These results suggest that no immune response was elicited in this individual. This subject was re-evaluated in January $24^{\text {th }}$ (six months later), showing an antibody response of $2.37 \mathrm{Log}_{10} \mathrm{mIU} / \mathrm{ml}$ in a test with a baseline of $1.98 \log _{10} \mathrm{mlU} / \mathrm{ml}$.

\section{DISCUSSION}

The recommended dose for immunization with yellow fever vaccine was standardized after clinical trials performed during the establishment of vaccine production in the late 30's. A dose of vaccine equivalent to $10^{3} \mathrm{MLD} 50$ was recommended as the minimum dose required to induce a satisfactory immune response although smaller doses have shown to be able to immunize adult volunteers ${ }^{67}$ The use of doses above recommended had not yet been reported. The present study aimed to evaluate the immune response in individuals that have accidentally received doses above the recommendation.

Frequency of side effects (Table 1) and clinical observations of this group of individuals were not different from the observed in recipients immunized with normal doses of the vaccine ${ }^{4}$. The absence of preimmunization samples did not allow a clear 
understanding of the alterations detected in hepatic enzymes, since they could be due to diverse causes and were mild and transient.

Side effects and reactions to yellow fever vaccine comprise minor effects, hypersensitivity reactions and severe reactions. Minor effects include fever, headaches, body pains and muscular weakness and local reactions on the site of injection. Only $0.2 \%$ of vaccinated subjects are obliged to curtail regular activities. Hypersensitivity reactions are extremely uncommon and include rash, urticaria and asthma. Cases of encephalitis and other severe reactions including fatal cases of multiple organ system failure and hepatitis have been reported ${ }^{18}$. In Brazil, two fatal cases of haemorragic fever associated with yellow fever vaccine, suggesting idiosyncratic reaction have recently been reported ${ }^{13}$.

Protective antibodies may be detected on day fifth after vaccination and is present in approximately $50 \%$ of vaccinees by the sixth and seventh day and in almost all of them by the fifteenth day after vaccination ${ }^{214}$.
In one patient of this study, who presented no abnormal biochemical results, viremia was detected at the fifth day. Virus may be recovered from plasma of individuals vaccinated with the attenuated strain 17D and derived substrains on the second day after vaccination and virus titre increase until the fifth day after vaccination, being negative by the tenth day after vaccination and has shown to be inferior to viremia of individuals infected with wild-type virus ${ }^{9}$. The increase in studies of viscerotropism and neurotropism using non-human primates is an indication of viscerotropism in these tests ${ }^{15}$. The viremia detected in the subjects of this study did not correlate with viscerotropism .

The yellow fever vaccine produced in FIOCRUZ for a period of more than 60 years is very important and strategic for the disease control in the country. During this long period of its use it has been demonstrated that this vaccine is safe and efficient. The present evaluation confirms the safety of the 17-DD yellow fever vaccine.

\section{ACKNOWLEDGMENTS}

The authors are grateful to Eliana Moreira Costa, Cintya Márcia Santos and Karina Soares for their technical assistance.

\section{REFERENCES}

1. Chan RC, Penney DJ, Little D, Carter IW, Roberts JA, Rawlinson WD. Hepatitis and death following vaccination with 17D-204 yellow fever vaccine. Lancet 14:358:121-2, 2001

2. Fox JP, Cabral SM. The Duration of Immunity Following Vaccination with the 17D Strain of Yellow Fever Virus. The American Journal of Hygiene 37:93-120, 1943.

3. Freestone DS. Yellow Fever Vaccine. In Vaccines, Plotkin AS, Mortimer EA eds. $2^{\text {nd }}$ Ed. W.B. Saunders Company, Philadelphia, USA, 1994.

4. Freestone DS, Ferris RD, Weinberg AL, Kelly A. Stabilized 17D strain yellow fever vaccine: dose response studies, clinical reactions and effects on hepatic function. Journal of Biological Standardization 5:181-186, 1977.

5. Fundação Nacional de Saúde. Programa Nacional de Imunizações. Manual de Procedimentos para Vacinação. $3^{a}$ Edição. Ministério da Saúde, Brasília, 1994.

6. Lang J, Zuckerman J, Clarke P, Barrett P, Kirkpatrick C, Blondeau C. Comparison of the Immunogenicity and Safety of Two 17D Yellow Fever Vaccines. American Journal of Tropical Medicine and Hygiene 60:1045-1050, 1999.

7. Lopes OS, Almeida SD, Carvalho R. Studies on yellow fever vaccine. III - dose response in volunteers. Journal of Biological Standardization 16:77-82, 1988.

8. Martin M, Tsai TF, Cropp B, Chang GJ, Holmes DA, Tseng J, Shieh W, Zaki SR, Al-Sanouri I, Cutrona AF, Ray G, Weld LH, Cetron MS. Fever and multisystem organ failure associated with 17D-204 yellow fever vaccination: a report of four cases. Lancet 358:98-104, 2001.
9. Monath TP. Yellow Fever. In: Plotkin AS, Orenstein WA (eds) Vaccines. WB Saunders Company, $3^{\text {rd }}$ Edition. Philadelphia, 1999.

10. Nicolau AR. Produção da vacina Anti-Amarílica no Brasil Simpósio Internacional sobre Febre Amarela e Dengue. Cinqüentenário da introdução da Cepa 17D no Brasil. Rio de Janeiro Maio 15-19, 1988.

11. Penna HA. Production of 17D yellow fever vaccine. World Health Organization, Monograph Series 30: 67-90, 1956.

12. Stefano I, Sato HK, Pannuti CS, Omoto TM, Mann G, Freire MS, Yamamura AM, Vasconcelos PF, Oselka GW, Weckx LW, Salgado MF, Noale LF, Souza VA. Recent immunization against measles does not interfere with the efficacy of yellow fever vaccine. Vaccine 17:1042-1046, 1999.

13. Vasconcelos PF, Luna EJ, Galler R, Silva LJ, Coimbra TL, Barros VL, Monath TP, Rodigues SG, Laval C, Costa ZG, Vilela MF, Santos CL, Papaiordanou PM, Alves VA, Andrade LD, Sato HK, Rosa ES, Froguas GB, Lacava E, Almeida LM, Cruz AC, Rocco IM, Santos RT, Oliva OF, Papaiordanou CM. Serious adverse events associated with yellow fever 17DD vaccine in Brazil: a report of two cases. Lancet 358:91-7, 2001.

14. Wheelock EF, Siblay WA. Circulating virus, interferon and antibody after vaccination with the 17D strain of yellow fever virus. New England Journal of Medicine 273:194-198, 1965.

15. World Health Organization. Expert Committee on Biological Standardization. World Health Organization, Technical Report Series 872, 1998. 